\title{
Belgeo
}

Revue belge de géographie

$3 \mid 2016$

High-speed rail and the city: urban dynamics and tourism

\section{Editorial: Thinking beyond the cost-benefit analysis: the wider impact of high-speed rail on local development}

Marie Delaplace and Frédéric Dobruszkes

\section{OpenEdition}

\section{Journals}

Electronic version

URL: http://journals.openedition.org/belgeo/18166

DOI: 10.4000/belgeo.18166

ISSN: 2294-9135

Publisher:

National Committee of Geography of Belgium, Société Royale Belge de Géographie

Electronic reference

Marie Delaplace and Frédéric Dobruszkes, « Editorial: Thinking beyond the cost-benefit analysis: the wider impact of high-speed rail on local development », Belgeo [Online], 3 | 2016, Online since 30 September 2016, connection on 23 September 2020. URL : http://journals.openedition.org/belgeo/ 18166 ; DOI : https://doi.org/10.4000/belgeo.18166

This text was automatically generated on 23 September 2020

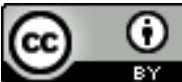

Belgeo est mis à disposition selon les termes de la licence Creative Commons Attribution 4.0 International. 


\title{
Editorial: Thinking beyond the cost- benefit analysis: the wider impact of high-speed rail on local development
}

\author{
Marie Delaplace and Frédéric Dobruszkes
}

1 This special issue is one of two published following the conference "High-speed rail and the city", held at the Paris-Est University in January 2015. The other has been published in Open Transportation Journal, 2016, Volume $10^{1}$. No fewer than 60 researchers from ten different countries discussed nearly 30 papers related to the two main themes, namely "High-speed rail and urban dynamics" and "High-speed rail and tourism".

2 This conference was the culmination of a European research process organised by the research group, "City, Transport, Tourism and Territory", which was supported by the Paris-Est University's “Urban Futures" Labex ("Laboratoire d'excellence"). This scientific work was undertaken during a series of international workshops held in Paris, Naples, and Toledo in 2013 and 2014. More than 20 researchers from the Alicante, Brussels (ULB), Castilla la Mancha, Lleida, Rovira y Virgili, Naples, and Paris-Est universities took part in these fruitful workshops. As guest editors of this issue, we would like to warmly thank the "Urban Futures" Labex for its support.

\section{The significant but contested development of high- speed rail}

3 Since the seminal "Tokaido Shinkansen" opened in 1964, connecting Tokyo and Osaka at $210 \mathrm{kph}$ (before subsequent improvements allowed higher speeds), high-speed rail (HSR) has expanded increasingly, especially across East and Southeast Asia and Western Europe. Considering at least $250 \mathrm{kph}$ (a threshold today commonly accepted to define high-speed rail), one counts nearly 29,000 km of high-speed lines (HSLs) across 13 countries in early 2016 (Figure 1), with 15,000 km more being constructed and 
thousands of extra km "planned" at a longer, thus uncertain term². Furthermore, in several European countries including France, Germany, and Italy, high-speed trains (HSTs) can also ride on incumbent, traditional tracks, indicating an actual space of operations much larger than suggested by the geography of the sole HSLs.

Figure 1. High-speed rail countries (2016).

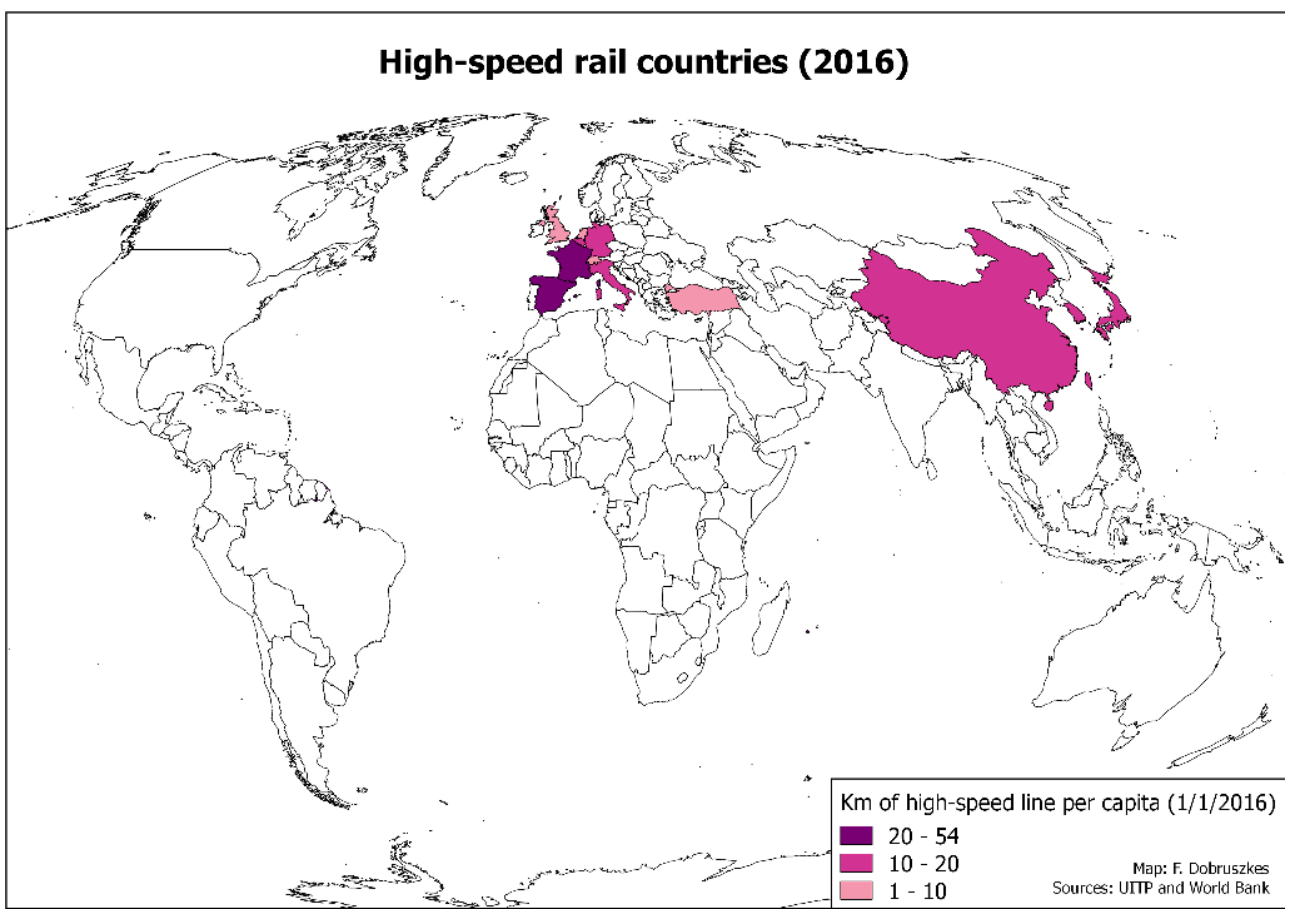

ONLY LINES OPERATINg AT 250 KPH MINIMUM HAVE BEEN CONSIDERED. (see Albalate and Bel, 2017, for a recent example). As we already noted some years ago:

-speed rail is a controversial issue (i.e., in political circles, on public, television, etc.) and so is the financing of transport facilities in countries as diverse as France, the UK or the US. The public debate was (and still is) quite lively in the UK and has fed on experts' reports and soundly-argued second opinions. HSR is also the subject of lively academic discussions as shown by a recent series of viewpoints published by the Journal of Transport Geography (Goetz, 2012) 'Should we build HSLs?" (Delaplace and Dobruszkes, 2013).

It is clear that this statement is even more valid today. Projects in countries as diverse as the UK, USA, Morocco, Australia and France have been (or are being) criticised.

The reasons for contesting HSR projects are diverse. Of course, there are local protests induced by the impact of new infrastructures in terms of noise, visual intrusion and land use. But most criticisms concern the very principle of building HSLs. The key point is that, since very few projects are financially profitable, public expenditures are required in most cases. This involves three different types of criticism. First, it irritates many observers, who by principle are against public spending, especially in AngloSaxon countries. Second, it is often argued that the whole community would be wiser to apply similar levels of public expenditures on modernising (longer parts of) traditional railways or on urban public transportation instead of on HSR (e.g., Overman, 2011). A 
related issue, too rarely pointed out, is that, on average, HSTs are overused by travellers belonging to higher social and occupational groups. In France, for instance, higher social-occupational groups account for $37 \%$ of the Mediterranean HSR and for $46 \%$ of the Northern HSR, compared to $8 \%$ of the whole population (Conseil général de l'environnement et du développement durable, 2008). This is notably a consequence of premium fares, which may account for a significant share of average monthly income. In France, for instance, a Paris-Marseilles return ticket may cost up to $18 \%$ of the 2013 per capita median net salary (Delaplace and Dobruszkes, 2015). This is arguably even truer in emerging countries. Thus, a Beijing-Shanghai return is priced at about RMB 1,100 or EUR 147. Considering the purchasing power parity between China and Belgium, this actually converts to no less than EUR 642. As a result, some have argued that public spending on HSR simply means that taxpayers pay for the mobility of the richer ${ }^{3}$.

But the very widespread criticism against HSR is the expected negative balance between costs and benefits. Considering financial terms only, most HSRs are simply not profitable, because very high traffic density is required to counterbalance high infrastructure costs. For instance, Betancor and Llobet (2017) note that, in Spain, virtually no HSR project is self-supporting, including the trunk line between Madrid and Barcelona (even though one could argue that the annual cost spread over 50 years is actually not so large). Of course, social costs and benefits are also considered. But most authors agree that even considering social costs and benefits - instead of financial terms only - still leads to the conclusion that high traffic density is needed to deliver a positive benefit-cost ratio.

\section{The weaknesses of cost-benefit analyses to assess HSR projects}

9 However, it is worth noting that the use of social cost-benefit analysis (CBA) to assess HSR projects is, by nature, an unstable and partial exercise. A CBA is unstable (i.e. not robust) because its results are strongly affected by the underlying hypotheses related to traffic and to the valuation of costs and benefits. It is well known that forecasts for rail projects are widely wrong, as they tend to overestimate the traffic and underestimate the financial cost (Flyvbjerg et al., 2005; Bonnafous, 2014). Table 1 gives some examples of error magnitude. Such wrong estimates are really problematic, considering that traffic density is a key factor of HSR financial and social profitability. In addition, ex post figures on HSR ridership suggest that, in many cases, not many passengers have actually been transferred from planes and cars, involving limited environmental gains (Givoni and Dobruszkes, 2013).

\begin{tabular}{|l|l|l|l|l|}
\hline HSR & Study year & Forecast passengers & $\begin{array}{l}\text { Observed } \\
\text { passengers }\end{array}$ & Difference \\
\hline Taiwan (daily) & $<1997$ & 200,000 & $35,000-50,000(2007)$ & $-83 \%$ to $-75 \%$ \\
\hline & & & $84,000-90,000(2008)$ & $-58 \%$ to $-45 \%$ \\
\hline Cross-Channel (Eurostar) & 1998 & $25 \mathrm{~m}$ in 2006 & $9.7 \mathrm{~m}$ en 2011 & $-61 \%$ \\
\hline
\end{tabular}




\begin{tabular}{|l|l|l|l|l|}
\hline France's TGV Nord & $1990 \mathrm{~s}$ & $10.9 \mathrm{~m}$ in 1993 & $6.4 \mathrm{~m}$ en 2002 & $-41 \%$ \\
\hline
\end{tabular}

But even supposing that experts hold robust estimates of expected traffic and investment costs, a CBA remains unstable because of all the hypotheses proposed about the alleged monetary value of social costs and benefits, including impacts on landscapes, time saved, decrease in accidents, and decrease in the emission of GHG and of pollutants. To cite but one example, a critical review of the British HS2 project by Castles and Parish (2011) has suggested that its benefit-cost ratio (BCR) may decrease from 1.6 (according to the government) to only 0.5 if four crucial parameters are revised (namely: traffic forecast, saturation of existing lines into the base case, time value, and the project's operating life). Only lowering the value of time (supposing that travel time penalises business passengers less than before, because laptops and ICTs make it possible to work on board) would reduce the BCR from 1.6 to 1.2. In this context, manipulating the conclusions of a CBA seems easy.

11 The second main issue raised by CBAs includes all of the impacts that are disregarded because they cannot be reasonably forecast and/or valued. These especially concern the potential indirect, wider impacts of HSR on the local economy, including the boost of tourism, establishment of new firms, establishment of companies, property value gains, new offices around rail stations, and changes in the social patterns of stations' neighbourhoods, that are significantly expected by private and public stakeholders promoting HSR. The latter also expect symbolic impacts in terms of the image of the city. HSR would contribute to bring places served into the modern era. Political plays and issues and the need to be modern are thus significant factors in understanding what happens locally as a result of HSR.

In previous research, we have suggested applying service innovation theories to transportation (Delaplace, 2012; 2016). HSR services can be analysed as a set of innovations related to stations, trains, services (access to new services and to new functionalities), and even sometimes the rail station's neighbourhood or the whole city through its new image. This set of innovation varies from country to country and from city to city because of technical, economic, institutional, social, and cultural aspects. It also varies due to the fact that public authorities conduct policies (communication, land planning, urban transport, etc.) to accommodate HSR in cities. These policies take place before, at the time of, or sometimes also after the launch of HSR services. Finally, the fact that such innovation exists does not necessarily involve effects. Indeed, these innovations need to be used and even be appropriated by private companies and inhabitants. The former can appropriate the innovations through market strategy, location strategy, career mobility, etc., and the latter can appropriate them through tourism-purposed mobility, commuting, and residential mobility. Hence, we know that tourism mobilities are very country- and culture-specific.

13 As a result, HSR cannot be considered as inducing mechanical/automatic effects on a city or a territory. The potential effect is co-produced in space and time by the various (public and private) actors, including the travellers. As written by Loukaitou-Sideris et al. (2013, p. 630):

14 “HSR's effect on economic and urban development can be characterized as analogous to a fertilizer's effect on crop growth: it is one ingredient that could stimulate economic growth, but other ingredients must also be present." As a result, it is necessary to 
investigate local patterns and relationships between stakeholders to understand the potential impacts of the HSR.

15 We understand from this discussion that issues are more complex than the simplified universe in which CBAs are most often designed.

\section{Contents of this special issue}

Thinking beyond the usual terms of CBAs is the common approach of papers published in this special issue. Papers gathered also have in common a focus on case studies related to Spain and France; that is, the two European countries with the largest HSR networks. Three papers are concerned with public action (Bellet Sanfeliu and Santos Ganges; Nègre and Baudelle; Delage), while the two following works investigate individual decisions through surveys among HSR travellers (Saladié, Anto Clavé, and Gutiérrez; Delaplace, Pagliara, and La Pietra).

Carmen Bellet Sanfeliu and Luis Santos Ganges explore the case of Saragossa and Valladolid, two medium-sized Spanish cities served by HSR since 2003 and 2007, respectively. They show how HSR has provided an opportunity to rethink the whole railway system within the city and, above all, to plan urban projects based on property developments. These projects were designed during a time of economic expansion that occurred over the 1990s and 2000s and that was notably based on a property boom. The major crisis beginning in 2008 suddenly halted these projects. Developers thus could not collect the expected revenues that had made projects feasible. In the end, if HSR has contributed to the main urban projects, the expected impacts have not been seen. In a period of economic downturn, a support policy is not enough to make projects successful.

Romaric Nègre and Guy Baudelle analyse the Bretagne-Pays de la Loire high-speed line (BPL HSL) being constructed between Le Mans and Rennes, France, as an extension of the existing Paris - Le Mans HSL . The line would open in 2017. In the context of Rennes' metropolitanisation process, ambitious urban projects have also been set up. The authors highlight the specific nature of the metropolitanisation context in which HSR is embedded to better understand the projects led. But they also highlight that beyond support public policies that aim to take advantage of HSR, the economic situation is again essential. It is too early to assess the impacts, but the paper suggests that, in an adverse economic context, even proactive public policies are not enough.

The first series of papers ends with Aurélie Delage's investigation of the recent regeneration process around Saint-Etienne's Châteaucreux rail station, France. The city has been served by HSR ${ }^{5}$ since as early as 1981 , but in the 1980 s, very few projects have been designed considering the context of a shrinking city (the city has lost more than 40,000 inhabitants between 1968 and 1999). However, since the 2000s, the rail station has been reconsidered as an opportunity to base economic renewal on the local public authorities' perspective and as "an all-risk insurance" for private stakeholders. Well beyond supply-related considerations - e.g., only four daily HSR services to Paris - the station has consciously been used as a core element to modernise the city with the support of renowned architects. While local developers may play a core role in certain cities in making projects realities (e.g., in Reims, see Bazin et al., 2016), it is found that, in the case of Saint-Etienne, external developers have played such a role. Again, only a 
detailed knowledge of local processes is needed to understand the potential advent of impacts.

The two following papers are interested in tourism as a business that can be stimulated by HSR. Both use quantitative methods based on a survey conducted among HSR users (Saladié et al.) or among two theme parks visitors (Delaplace et al.). They shed a light on users' behaviours that have received too little attention until now.

Oscar Saladié, Salvador Anton Clavé et Aaron Gutiérrez surveyed 1,225 HSR travellers at the Camp de Tarragona HSR station (14 km away from Tarragona city and $17 \mathrm{~km}$ away from Reus, Spain) and considered a causal approach. They find that the HSR station increases the probability to visit Costa Daurada by $24 \%$ for tourists that had never been there before and by $13 \%$ for the repeaters. This confirms that HSR can stimulate tourism, but on the other hand, HSR accounts for only $3 \%$ of tourists visiting this resort. This suggests that tourism is not enough to justify the expensive investment in HSR infrastructure.

Finally, Marie Delaplace, Francesca Pagliara, and Andrea La Pietra analyse the impact of HSR in tourists' destination choice considering two theme parks, namely the Futuroscope close to Poitiers and Disneyland Paris in Marne-la-Vallée, France. Both are located near an HSR station. Again, the results show that the territorial context is key to understand the relationships between HSR and economic development, including tourism. Indeed, while regression techniques show that tourists would have not visited Disneyland Paris without HSR, this is not the case for Futuroscope, where HSR users are much fewer (14\% compared to $46 \%$ for Disneyland). Results also show that HSR does not affect the spatial diffusion of tourists around theme parks. At Disneyland, diffusion occurs towards Paris thanks to the regional express rail network (RER). In contrast, from Futuroscope diffusion occurs by car, and in a larger space within Poitou-Charente region, especially towards the cities of La Rochelle and Poitiers.

All in all, the papers gathered show the extent to which relationships between HSR and local dynamics are context-related and, notwithstanding the characteristics of the HSR supply, deeply related to territorial contexts, to local public policies, to the economic context, to behaviours, and to users' attributes. Of course, these five papers do not exhaust the topic. We think it is necessary to compare these results with other cases to cover more local and national contexts. The results of the existing CBAs would probably not be reversed, but this at least makes it possible to set up the foundations for multicriteria analyses. Finally, we hope that this paper will arouse similar research in countries with recent HSR development, especially in China but also in other developing/emerging countries.

\section{BIBLIOGRAPHY}

ALBALATE D., BEL G. (eds.) (2017), Evaluating high-speed rail: Interdisciplinary perspectives, Abington \& New York, Routledge. 
BAZIN S., BECKERICH C. \& DELAPLACE M. (2016), “High-speed rail, corporate real estate and firm location: the results from two surveys $(2008 ; 2014)$ in Reims", Open transportation journal, 10, pp. 7-21.

BETANCOR O., LLOBET G. (2017), "Financial and social profitability of HSR in Spain”, in ALBALATE D., BEL G. (eds.), Evaluating High-Speed Rail: Interdisciplinary perspectives, Abington \& New York, Routledge, pp. 23-45.

BONNAFOUS A. (2014), "Permanent Observatories as Tools for Ex-Post Assessment: The French Case Study", ITF-OECD Discussion Paper, 10, Paris, International Transport Forum.

CASTLES C., PARISH D. (2011), Review of the Economic Case for HS2 Economic evaluation London - West Midlands link, London, RAC Foundation.

CONSEIL GÉNÉRAL DE L'ENVIRONNEMENT ET DU DÉVELOPPEMENT DURABLE (2008), Rapport sur les bilans LOTI : - de la LGV Rhône-Alpes; - de la LGV Méditerranée; - des gares nouvelles des LGV RhôneAlpes et Méditerranée, doc no. 005448-01.

DELAPLACE M. (2012), « Pourquoi les 'effets' TGV sont-ils différents selon les territoires? L'hétérogénéité au cœur du triptyque 'Innovations, Territoires et Stratégies' ", Recherche Transports et Sécurité, 28, pp. 290-302.

DELAPLACE M. (2016), « Grande vitesse ferroviaire et développement local dans des contextes institutionnels différents : la nécessité de spatialiser les analyses de l'innovation de services », Le Forum de l'Innovation VII, 20 ans d'Innovations, Cité des Sciences et de l'Industrie, Paris, 9-11/6/2016.

DELAPLACE M., DOBRUSZKES F. (2013), “Analysing the relationship between high-speed rail and territories: a scientific field still in-progress", Introduction to special issue, Recherche Transports et Sécurité, 29, pp. 155-160.

DELAPLACE M., DOBRUSZKES F. (2015), "From low-cost airlines to low-cost high-speed rail? The French case", Transport Policy, 38, pp. 73-85.

FLYVBJERG B., SKAMRIS HOLM M. \& BUHL S. (2005), "How (in)accurate are demand forecasts for public works projects? The case of transportation", Journal of the American Planning Association, 71, 2, pp. 131-146.

GIVONI M., DOBRUSZKES F. (2013), “A review of ex-post evidence for mode substitution and induced demand following the introduction of High-Speed Rail”, Transport Reviews 33, 6, pp. 720-742.

GOETZ A. (2012), "Guest editorial: Introduction to the Special Section on rail transit systems and high speed rail”, Journal of Transport Geography, 22, pp. 219-220.

LOUKAITOU-SIDERIS A., HIGGINS H., PIVEN M. \& WEI W. (2013), “Tracks to Change or Mixed Signals? A Review of the Anglo-Saxon Literature on the Economic and Spatial Impacts of HighSpeed Rail", Transport Reviews: A Transnational Transdisciplinary Journal, 33, 6, pp. 617-633.

OVERMAN H. (2011), “HS2: assessing the costs and benefits”, CentrePiece Winter, 2011/12, pp. 18-20. UIC (2016), High-Speed lines in the World, Paris, UIC High-speed Department, Updated $1^{\text {st }}$ January 2016.

\section{NOTES}

1. See http://benthamopen.com/TOTJ/VOLUME/10/ 
2. Computations made by the authors based on UIC (2016). Lines under $250 \mathrm{kph}$ have been excluded.

3. For instance, Henry Overman's contribution to The Case for High-speed Rail: A regional, social and economic perspective, Parliamentary Seminar, London, Westminster Palace, 1st February 2012.

4. Rennes is already served by a high-speed train but riding on a traditional track from/to Le Mans.

5. Through a traditional track extending the Paris - Lyon HSR.

\section{AUTHORS}

\section{MARIE DELAPLACE}

Université de Paris-Est Marne-la-Vallée - Lab'Urba, Ecole d'Urbanisme de Paris, marie.delaplace@u-pem.fr

\section{FRÉDÉRIC DOBRUSZKES}

Université libre de Bruxelles - Facultés des Sciences - DGES-IGEAT,

frederic.dobruszkes@ulb.ac.be 